\title{
A CONTRIBUIÇÃO DA TEORIA DA ATIVIDADE PARA A CONSTRUÇÃO DE UM APP SOBRE O GÊNERO RESENHA DE FILME NO PROFLETRAS
}

\author{
THE CONTRIBUTION OF THE THEORY OF THE ACTIVITY FOR THE CONSTRUCTION OF \\ AN APP ON THE GENRE FILM REVIEW IN THE PROFLETRAS
}

\author{
Cláudia Valéria Doná Hila1, Vinicius da Silva Zacarias² \\ 1 Universidade Estadual de Maringá (UEM), Maringá, PR, Brasil \\ cvdhila@uem.com.br
}

2 Secretaria de Educação do Estado de São Paulo

viniciuszaca@yahoo.com.br

Recebido em 25 jul.2018

Aceito em 23 ago. 2018

Resumo: O processo de formação do professor do Mestrado Profissional em Letras enfrenta desafios similares aos da formação inicial. Dentre eles, o movimento de apropriação de novas teorias tem sido bastante desafiador ao professor formador do curso, justamente pelo fato de que são alunos, em nossa unidade, regra geral, há tempos afastados da academia. Se por um lado esses sujeitos apresentam maior facilidade com os conhecimentos práticos, por outro, o conhecimento científico se coloca como desafiador, tendo em vista o volume de disciplinas que têm a cumprir, bem superior ao de um programa acadêmico. Diante desse cenário, o objetivo deste artigo é discutir o movimento de internalização de um professor em formação na elaboração de um app do gênero resenha de filme. O foco está, sobretudo, nas ações e operações mobilizadas pela professora-formadora, que desencadeiam novas operações no aluno, com base na Teoria da Atividade (LEONTIEV, 1998; 2001; 2004). Os resultados evidenciam que o movimento de internalização necessita de várias operações, de uma parceria entre formador e aluno, de vários eventos, e, portanto, de tempo para que se consolide.

Palavras-chave: Formação do professor. Gêneros discursivos. Teoria da Atividade.

\begin{abstract}
The process of teacher formation of the Professional Master in Literature faces similar challenges to that of initial training. Among them, the apropriation movement of new theories has been quite challenging to the teacher teacher, precisely because they are students, in our course, as a rule, have been away from the academy for some time. If, on the one hand, these students are more comfortable with practical knowledge, on the other hand, scientific knowledge is challenging because, given the volume of subjects they have to attend, it is far superior to that of an academic program. In view of this scenario, the objective of this article is to discuss the internalization movement of a teacher-student in the elaboration of an app of the film review genre. The focus is mainly on the actions and operations mobilized by the teacher in formation, which trigger new operations in the student, based on the Theory of Activity (LEONTIEV, 1998; 2001. 2004)). The results show that the internalization movement requires several operations, several events, a partnership between teaher and student, requires multiple events, and therefore time to consolidate.
\end{abstract}

Keywords: Teacher training. Discursive genres. Theory of activity. 


\section{Introdução}

Uma das grandes dificuldades dos professores quando iniciam 0 Programa de Mestrado Profissional - PROFLETRAS, é a apropriação do conhecimento científico, após anos afastados da academia, como é o caso de nossa unidade. Essa dificuldade fica ainda maior, na medida em que o Programa exige o cumprimento de dez disciplinas, de epistemologias variadas, em um curto espaço de tempo.

No caso específico da disciplina "Gêneros discursivos/textuais e práticas sociais", o professor entra em contato com diferentes teorias que subsidiam o estudo com os gêneros discursivos, a fim de que possa, posteriormente, realizar a transposição didática, compreendendo os pré-construídos que deram origem a sua escolha metodológica. Nesse sentido, esperamos, como professores formadores (entendendo aqueles que efetivamente ministram aulas no ProfLetras), que os nossos alunos tanto se apropriem dos saberes envolvidos na disciplina, como também possam se desenvolver, por meio de ferramentas mediadoras neste processo.

Os pressupostos básicos do Interacionismo Sócio Discursivo nos orientam que o desenvolvimento dos indivíduos ocorre nas atividades sociais, em um meio constituído e organizado por pré-construídos e através de processos de mediação. Por isso mesmo, uma das tarefas dos professores formadores tem sido o de auxiliar esses professores a ressignificarem suas práticas em sala de aula, por meio da compreensão das teorias que explicam suas escolhas didático-pedagógicas. Para alcançarmos este objetivo, temos utilizado a Teoria da Atividade (TA) (LEONTIEV, 1998) como aporte teórico de base para constituirmos nosso trabalho de formação na sala de aula.

Nosso objetivo, portanto, neste artigo, é discutir como uma professoraformadora conduz o processo de apropriação de um professor em formação, no trabalho com os gêneros discursivos, por meio da construção de um app sobre resenha de filme, desenvolvido durante a disciplina "Gêneros 
textuais/discursivos e práticas sociais", no ano de 2018. Para tanto, apresentamos na primeira seção os aportes teóricos da Teoria da Atividade, na sequência discutimos as operações mobilizadas pela professora formadora, anteriores à construção do app, a apresentação do app, seguida de nossas discussões finais.

\section{A Teoria da Atividade como ferramenta da professora formadora para gerar apropriação no professor em formação do PROFLETRAS}

A Teoria da Atividade (TA) desenvolvida por Leontiev e seguidores (Rubstein, Luria e Davydov) é considerada uma continuidade das ideias de Vygotsky, tido um dos precursores da teoria psicológica da atividade. $\mathrm{Na}$ realidade, muito embora Vygotsky tivesse se detido em compreender 0 processo de internalização, é com Leontiev que esse processo, denominado por ele agora de apropriação, chega a categorias mais explicativas.

Ao compreender como se dá a apropriação dos instrumentos pelos homens, discutida nas obras de Leontiev $(1998 ; 2001 ; 2004)$, pode-se, de forma análoga, entender, por meio dessa teoria, como ocorre a apropriação de um conteúdo científico por meio do conceito de atividade e como esse conceito pode auxiliar professores formadores a planejarem suas aulas, com vistas a auxiliar o professor em formação no processo de internalização e de transposição didática.

As atividades humanas, para Leontiev (2004), são consideradas como formadoras das relações do sujeito com o mundo, dirigidas por motivos, por fins a serem alcançados. A ideia de atividade envolve então a noção de que o homem se orienta (no caso da aprendizagem) por objetivos, agindo de forma intencional, movido por ações que necessitam ser planejadas. No entanto, existe uma diferença entre atividade e ação. Uma ação é um processo cujo motivo não coincide com seu objeto (ou seja, com aquilo para o qual ele se dirige), mas reside na atividade da qual ele faz parte. A ação individual nesse 
contexto só adquire sentido quando está integrada à atividade. Dessa forma, nem sempre um professor em formação, ao estudar, está em atividade, mas somente quando o motivo (componente de natureza mais emocional) corresponde à atividade. Quando, porém, o motivo não corresponde à atividade, normalmente, tem-se a memorização de um conceito sem a sua apropriação, o que nos leva a refletir sobre a importância de se instaurar motivos para o desenvolvimento do professor.

Para Leontiev (2001, p. 315) a atividade define-se como:

(...) aqueles processos que, realizando as relações do homem como o mundo, satisfazem uma necessidade especial correspondente a ela (...) Por atividade, designamos os processos psicologicamente caracterizados por aquilo que o processa, como um todo, se dirige (isto é é, objeto), coincidindo sempre com o objetivo que estimula o sujeito a executar essa atividade, isto é, o motivo. (LENTIEV, 2001, p. 315)

Se o motivo impulsiona o sujeito a realizar ações, para que possa aprender, Leontiev reforça, para que esse processo ocorra, a importância da atividade coletiva, na medida em que o próprio ambiente sociocultural pode desencadear motivos para a realização de novas ações do sujeito, que por sua vez, exigirão novas operações, as quais desenvolverão os processos psíquicos.

Os componentes desse movimento da atividade propostos por Leontiev (2001) são: necessidade- motivo- objetivos/finalidade-condições para se obter a finalidade. A estrutura geral da atividade estaria assim formada:

Quadro 1. Estrutura geral da atividade

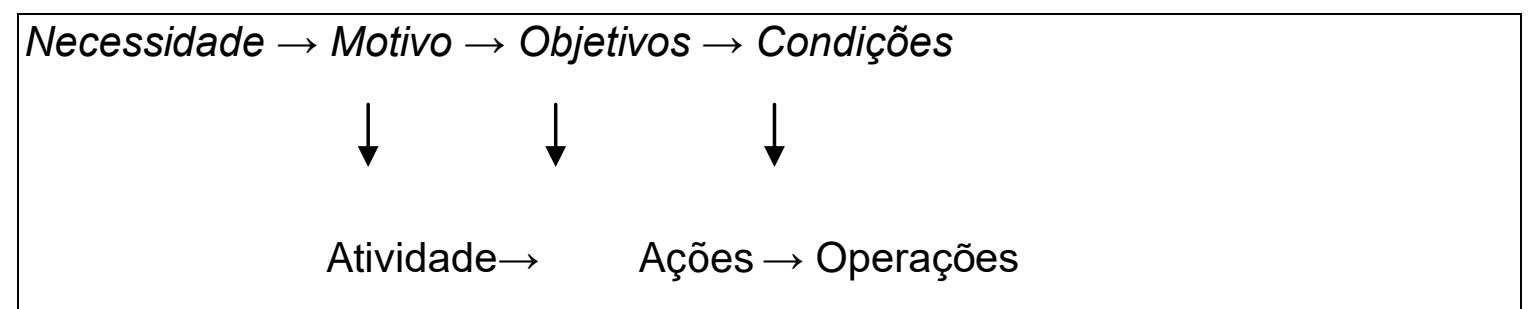

Fonte: Leontiev, 1998 
A necessidade é o fator que desencadeia a atividade, é o que leva o sujeito a ter objetivos e realizar as ações (SFORNI, 2004). Ela é um componente tão importante que Sforni acrescenta "nem todo processo é uma atividade, mas somente aquele que é movido por uma necessidade" (p.98). $\mathrm{Na}$ realidade, podemos afirmar que enquanto o motivo é de natureza emocional, a necessidade é de natureza racional. Podemos, assim, planejar uma atividade, por exemplo, a apropriação de um determinado gênero discursivo, partindo da ideia de que isso é importante para a formação do professor (aspecto racional), mas quando o gênero é escolhido pelo professor, motivado por desejos que lhe são próprios, teríamos o motivo. Assim, se o sujeito não vê sentido naquilo que realiza, logo não torna consciente o que faz, e se não tem consciência sobre as ações que realiza não é possivel qualficá-la de atividade. Neste caso, pode estar realizando uma tarefa (feita para cumprir uma obrigação) mas não está inserido numa atividade. Fichar uma obra, desenvolver uma proposta de intervenção, realizar um seminário ou construir um app tanto podem ser tarefas, que não geram internalização, como atividades, a depender das operações realizadas pelos professores-formadores e, também, pelos professores-alunos.

O motivo ou finalidade tem a ver com aquilo que se pretende naquela atividade, poderíamos associá-la ao objetivo. Para a realização desse objetivo serão necessárias as condições, ou seja,os meios para alcançá-lo por intermédio das ações e das operações. Em muitos casos, na sala de aula, professoes-formadores não conseguem proporcionar a internalização de cohecimentos científicos, porque param na ação, ou seja, despertam necessidades para uma ação em sala de aula, conseguem motivar, mas não planejam, especialmente, as operações necessárias para o fim desejado. Nesses casos, pode ocorrer, conforme Hila (2011), uma pseudo-apropriação, necessitando novos eventos formativos para que o conhecimento efetivamente se internalize. 
A ação, nesse sentido, é o processo cujo motivo não coincide com seu objeto, mas pertence á atividade. Leontiev (2004) ilustra essa afirmação ao explicar que a atividade de ler um livro, para apenas passar numa prova, ou a atividade de realizar um seminário ou mesmo um app, apenas para ser avaliado, não é, necessariamente, uma atividade, mas ações isoladas, porque ler o livro por ler não é um objetivo forte que estimula a ação para o processo de aprendizagem do sujeito.Todavia, a ação pode se tranformar em atividade quando passa a ter um motivo para o sujeito. No exemplo dado se o aluno começa a ler e a leitura acaba por envolvê-lo por alguma razão, o motivo da atividade desloca-se, transformando-se a ação em uma atividade.

Isso ocorre, com bastante frequência, no âmbito do Profletras. Muitas vezes, ações como apresentação em seminários, podem se constituir em atividade real de aprendizagem, quando o professor, ao realizá-la, mediado por operações necessárias, de responsabilidade também do professor formador, consegue se apropriar dos conhecimentos, mas, ao contrário, pode, também, se revelar uma mera tarefa dada, sem que em outras ações parecidas o professor em formação revele realmente a aprendizagem dos conteúdos.

Uma ação pode ser realizada de diferentes maneiras, designadas por Leontiev de operações, as quais consistem no modo de execução de uma determinada tarefa, ou nas palavras de Leontiev (1981, p.61) "denominarei operações os meios mediante os quais uma ação se leva a cabo". As operações, na realidade, são elementos determinantes para que a tarefa se transforme em atividade, porque de nada adiantará termos um aluno motivado para realizar uma ação se não oferecermos andaimes necessários para sua consecução. Por exemplo, para se apropriar de um determinado conteúdo o professor em formação pode realizar diferentes operações: leitura silenciosa, resumo, esquema, fichamento, ilustrações, oficinas etc. As operações, na realidade, tanto evidenciam a preocupação do professor-formador com 0 processo de aprendizagem do aluno, como abrem caminho para que esse 
mesmo professor instaure, também, conscientemente, novas ações e operações que ele irá seguir.Para Leontiev (2004), é um erro pensar que os sujeitos já tenham instaurado determinadas operações e que, por isso, não precisemos, como formadores, retomá-las, a fim de instaurar a atividade.

No caso do ProfLetras, recebemos professores com diferentes saberes teóricos e práticos. Mas, falta-lhes, muita vezes, coadunar o conhecimento teórico ao conhecimento metodológico e a sua prática. É necessário que o professor-formador pense em várias formas de ilustrar o processo de transposição didática, de mobilizar o conhecimento científico, além da mera exposição oral do conteúdo, a fim de que possa mobilizar diferentes processos de ensino e aprendizageme atingir o maior número possível de alunos.

Se as operações desenvolvidas pelo professor-formador realmente forem realizadas (porque há casos em que não são), estas, mais tarde, transformamse em apropriação, saindo da esfera dos processo conscientes e passando a ocupar um lugar inferior na estrutura da atividade. Mas, ocupar 'um lugar inferior' não signifia simplificar o estatuto da operação, ao contrário, significa afirmar que houve um processo de apropriação que agora torna-se consciente e que, em tornando-se consciente, deixa livre o pensamento para se incumbir de novas ações e novas operações, de caráter mais elevado.É nessa passagem da ação para a operação que ocorre um grande movimento de aprendizagem e de internalização para Leontiev (1998). Esse fato gera o que Vygotsky (2001) denomina de "automatismo psíquico", considerado uma condição psicológica necessária para o surgimento de tipos superiores de atividade, num processo que é ad infinitum.

Um dos problemas que pode ocorrer tanto na universidade como na escola, pensando na passagem da ação para a operação, é o fato de o professor-formador utilizar-se de muito trabalho de exposição de conteúdos e poucos se pensando na ação, ou seja na passagem da teoria para a prática. No caso do processo de transposição didática dos gêneros do discurso, é 
necessário, além das leituras teóricas, que o professor formador ilustre metodologicamente várias formas de se transpor o gênero discursivo na sala de aula e dê espaços para que o professor em formação possa, com a devida mediação, também construir suas ações.

Assim, pensando na contribuição da TA para a aprendizagem do professor que recebemos teríamos que o professor-formador, ao pensar em uma ação, necesssita gerar uma necessidade nos alunos e uma finalidade. A ação, que, por sua vez, mobiliza operações, as quais são realizadas, inicialmente, pelo professor-formador. As operações, quando bem sucedidas, encerram uma atividade, ao mesmo tempo que podem conduzir a uma nova atividade, agora mais complexa, promovendo, assim, o desenvolvimento de novos processos superiores. Só ocorrerá apropriação de um determinado conteúdo quando se criaram novas funções psíquicas, caso contrário o ensino cai na mera reprodução.A passagem de uma ação para uma nova operação de caráter mais elevado dependerá da finalidade nova estabelecida pelo professor- formador como se vê no quadro abaixo:

Quadro 2. Movimento da aprendizagem na Teoria da Atividade

xxx...
$\uparrow$
Operação $\rightarrow$ Ação $\rightarrow$ Atividade mais complexa
$\uparrow$
Operação $\rightarrow$ Ação $\rightarrow$ Atividade mais complexa
$\uparrow$
Atividade $\rightarrow$ Ação $\rightarrow$ Operação

Fonte: os autores 
Esse movimento revela, para Leontiev, o processo contínuo de aprendizagem e de desenvolvimento. A apropriação, portanto, na TA, necessita de determinados procedimentos conscientes, por parte do professor-formador, para que ela ocorra.

\section{A Teoria da Atividade no contexto da disciplina "Gêneros discur- sivos/textuais e práticas sociais"}

$\mathrm{Na}$ seção anterior, explicamos que, para promover a apropriação e o desenvolvimento de algumas habilidades do professor agora visto, também, como aluno, faz-se necessário colocá-lo dentro de uma atividade, que se inicia por motivos, desencadeado por ações e operações para alcançá-los. No caso da nossa disciplina, a construção de um app, a partir de um gênero do discurso (ação principal), foi a etapa final da ação principal - apropriar-se de um gênero discursivo para realizar uma proposta de intervenção, inicialmente, motivada pela leitura de capítulos do livro "Multiletramentos na escola", de Roxane Rojo e Eduardo Moura (2012), na qual os autores lançam questionamentos a respeito de novos modos de ensinar e dialogar nas práticas escolares por meio das novas tecnologias.

Da discussão coletiva das ideias do livro, surgiu a ideia da produção de um aplicativo para celular, mas havia um problema: nenhum dos alunos jamais havia desenvolvido um aplicativo, nem tão pouco a professora-formadora. No entanto, antes que dirigíssemos nossa atenção para isso, era necessário pensar, primeiro na apropriação de conteúdos que iriam no aplicativo.

As operações para que o desenvolvimento do conteúdo do aplicativo foram várias, dividindo-se em duas etapas: a primeira de natureza coletiva (para toda a sala), e a segunda individual (para alunos que fossem criar o app). As operações, de caráter coletivo foram: 
a) primeira operação: leitura roteirizada e discussão de textos teóricometodológicos acerca da transposição didática dos gêneros discursivos para o ensino. De forma específica, ressaltamos os aportes teórico-metodológicos e estudo do gênero a partir do Interacionismo Social, do Interacionismo Sócio Discursivo, da Sócio Retórica e da Análise Crítica do Discurso;

b) segunda operação; elaboração de esquemas mentais de cada uma dessas teorias, coadunando aspectos teóricos aos metodológicos;

c) terceira operação: discussão de aportes teóricos da Base Nacional Curricular Comum, acerca dos gênero do discurso;

d) quarta operação: ilustração de atividades de leitura, escrita e análise linguística,a partir da concepção dialógica/discursiva de linguagem;

e) quinta operação:estudo teórico-prático de algumas metodologias de trabalho com os gêneros discursivos em sala de aula, a partir, principalmente, do Interacionismo Social e do Interacionismo Socio Discursivo, a saber: Sequência Didática (DOLZ, NOVERRAZ, SHENEUWLY,2004); Sequência didática adaptada (HILA e NASCIMENTO, 2009 ; SWIDERSKI e COSTA-HUBES, 2009); Projeto de leitura e escrita a partir dos gêneros discursivos (LOPESROSSI, 2008); Projeto didático de gênero (GUIMARÃES e KERSCH,2014); Elaboração didática (HALTÉ, 2008); Protótipo didático (ROJO e MOURA, 2012), Projeto de letramento (OLIVEIRA, TINOCO e SANTOS, 2014); Projeto temático de gênero a partir dos campos da linguagem (MIGLIOLI, 2018);

f) sexta operação: relação entre as metodologias e as teorias de base;

g) sétima operação: estudo da plataforma "Fábrica de aplicativos".

h) oitava operação: ilustração de um app desenvolvido por outros professores em formação de outra unidade do Profletras.

O estudo de todas essas metodologias, em conjunto com os seus respectivos aportes teóricos, foram, sem dúvida, operações muito significativas tanto para a apropriação dos conhecimentos científicos, como também 
metodológicos. Após esse trabalho, os professores ficaram mais confiantes para desenvolverem sua proposta, alguns, inclusive, modificaram ou adaptaram essas propostas já para o trabalho de intervenção da dissertação.

Depois disso, iniciamos, já quando os alunos já tinham definido o gênero a ser trabalhado, trouxe, como ilustração um app denominado "SD_LP", disponível para sistema Android, no Play Store e desenvolvido por alunos do ProfLetras da Universidade Federal do Pará (UFPA). O aplicativo foi visto com bastante entusiasmo pelos professores -alunos da turma. Assim, propusemos a elaboração também de um app como forma de avaliação da disciplina.

Diferentemente dos alunos da UFPA, que contaram com um programador para fazerem e incluírem o app no Play Store, nosso trabalho foi um pouco diferente. Encontramos uma plataforma gratuita (já que o custo de um programador não era viável) - Fábrica de aplicativos, a qual se mostrou bastante didática para a tarefa. Assim, resumidamente os elementos da Teoria da Atividade ficaram configurados, no plano coletivo da professora formadora:

Quadro 3. Elementos da Teoria da Atividade desenvolvidos pela professosra formadora disciplina do curso

\begin{tabular}{|l|l|}
\hline Elementos da Teoria da Atividade & Descrição \\
\hline Necessidade & $\begin{array}{l}\text { Realizar uma avaliação ao final da } \\
\text { disciplina Gêneros } \\
\text { discursivos/textuais e práticas sociais }\end{array}$ \\
\hline Finalidade ou objetivo & $\begin{array}{l}\text { Produzir um proposta de intervenção } \\
\text { a partir de um gênero discursivo }\end{array}$ \\
\hline Ação principal & $\begin{array}{l}\text { Desenvolver um app que inclua uma } \\
\text { proposta de intrvenção a partir de um } \\
\text { gênero discursivo }\end{array}$ \\
\hline Operações & $\begin{array}{l}\text { 1. Ler e discutir textos de natureza } \\
\text { teórica que estudam o gênro } \\
\text { discursivo textual (definimos a } \\
\text { perspectiva do Interacionismo Social, } \\
\text { do Interacionismo Socio Discursivo, } \\
\text { da Análise Crítica do discurso e da }\end{array}$ \\
\hline
\end{tabular}




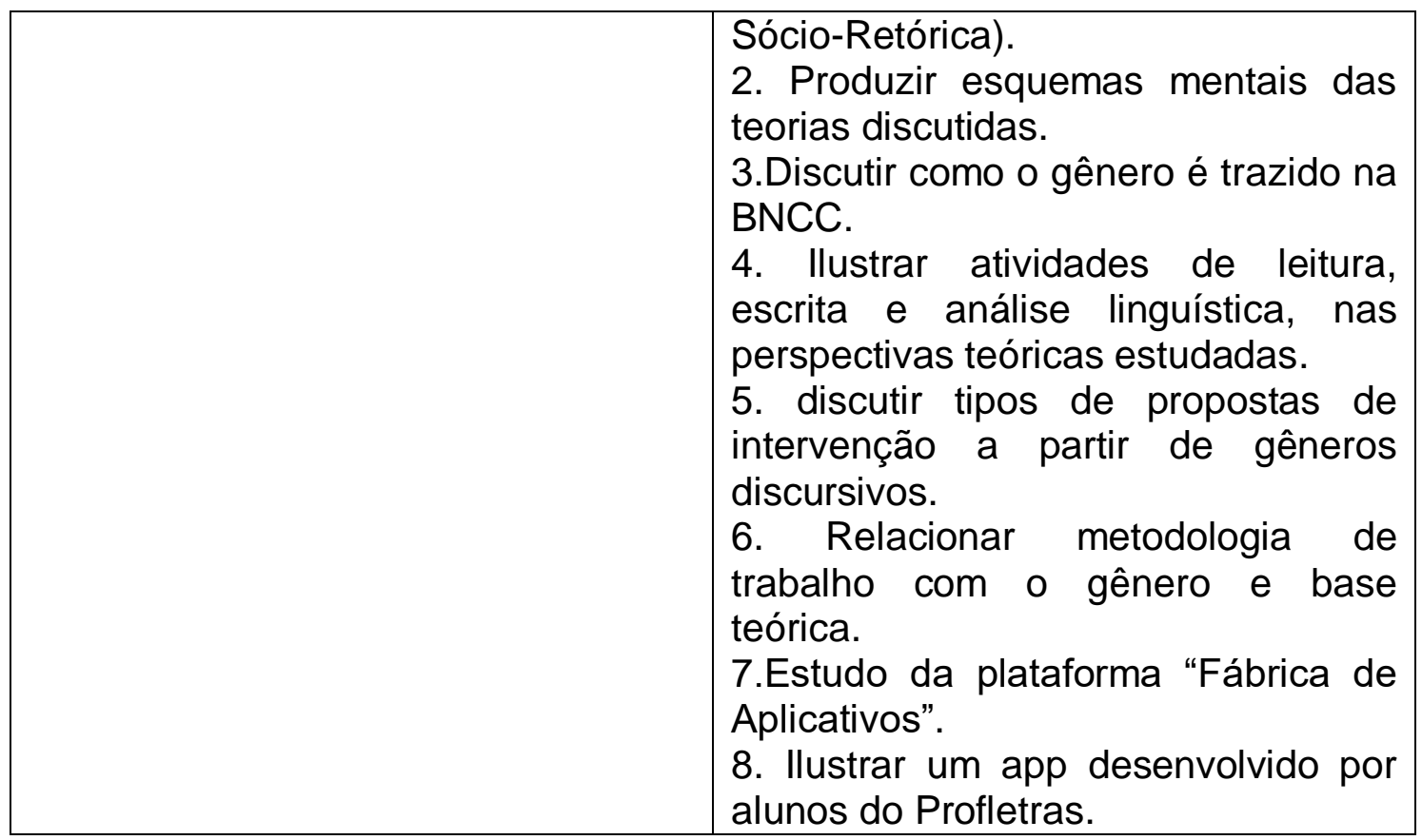

Fonte: os autores

Reiteramos que a intenção com a construção do app era, na verdade, além do próprio aprendizado da ferramenta, principalmente o seu conteúdo, para possível uso na sala de aula. Como a plataforma é gratuita não foi possível alocar os apps no Play Store, assim eles serão linkados na página do programa - www.profletras.uem.br , a partir do segundo semestre de 2018. Ao todo foram produzidos seis apps, já que foi possível o trabalho em duplas.

Além do plano coletivo da ação, das operações visando diferentes ações, no plano individual a professora formadora orientou para o professor-aluno o desenvolvimento de outras ações de operações, que foram:

a) escrita de um modelo didático do gênero, de acordo com a série;

b) elaboração do app;

c) participação em evento para divulgar app;

d) reedição do app com base nos comentários quando da apresentação do evento; 
e) escrita de um artigo científico.

Na verdade, a última operação se faz na escrita deste artigo, como forma de coadunar todas as ações anteriores desenvolvidas tanto pela professoraformadora, como pelo professor-aluno.

Na próxima seção expomos a costrução de um deles a partir do gênero resenha de filme.

\section{O app resenha de filme}

Tendo em vista as discussões apresentadas até então, e outras mais realizadas no âmbito da disciplina de Gêneros textuais/discursivos e ensino, foi desenvolvido o $a p p^{1}$ que apresentamos a seguir, intitulado Resenha de filme. Destacamos que este app tem como interlocutor o aluno do contexto do campo, no qual o professor-aluno trabalha. Esse contexto é bastante carente, tanto de materiais didáticos adequados, quanto de metodologias mais atraentes, o que motivou, portanto, a construção do app mais informativo que prático pelo professor-aluno. Além disso, ele passou por algumas reedições, após ser apresentado em um evento no ano de 2018 (ZACARIAS e HILA, 2018).

A tela inicial do app apresenta o menu raiz, a partir do qual o usuário pode acessar todo o conteúdo proposto: definição do gênero, contexto de produção, conteúdo temático, estrutura composicional, estilo, recapitulação, passos para a produção, exemplos de resenha e referências.

\footnotetext{
${ }^{1}$ Para o desenvolvimento da ferramenta, utilizamos o site Fábrica de Aplicativos, que oferece serviço gratuito para criação de aplicativos. - www.fabricadeaplicativos.com.br. O acesso ao app pode ser feito através do seguinte link: https://app.vc/resenha de filme
} 
Figura 1 - Menu raiz

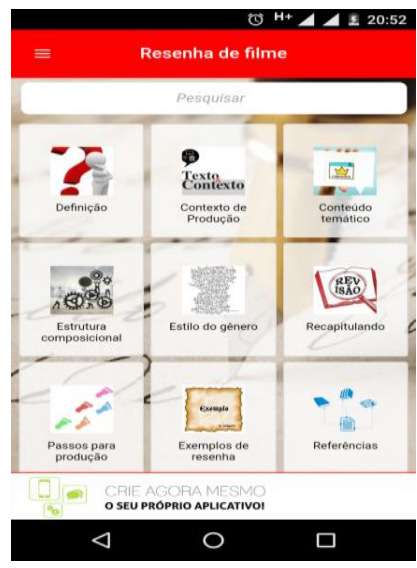

Fonte: Os autores

Ao acessar o item Definição, o usuário é encaminhado para uma tela na qual é apresentada a definição do gênero resenha de filme tendo por base os estudos de Machado; Lousada; Abreu-Tardelli (2004), bem como de Barros (2008) e Lima (2015)

Quadro 4- Definição do gênero

\begin{tabular}{|l|l|}
\hline A resenha de filme é um texto que se originou \\
com a criação do cinema. Assim como as pessoas \\
liam livros e buscavam comentar o que liam uns \\
com os outros, com os filmes não era diferente. \\
Com o tempo, intelectuais e especialistas \\
decidiram publicar seus comentários e impressões \\
a respeito dos filmes que assistiam em veículos \\
de comunicação, como jornais e revistas, dando \\
origem, assim, ao gênero resenha fílmica ou \\
crítica de cinema, no qual um autor apresenta um \\
filme a seu leitor, faz uma descrição dele, resume \\
seu enredo de forma superficial e faz uma \\
avaliação sobre a obra. Segundo Machado, \\
Lousada e Abreu- Tardelli (2004, p.15):
\end{tabular} \mid \begin{tabular}{l} 
Inúmeros tipos de textos se caracterizam por \\
\hline
\end{tabular}

Pensares em Revista, São Gonçalo-RJ, n. 13, p. 137-164, 2018 


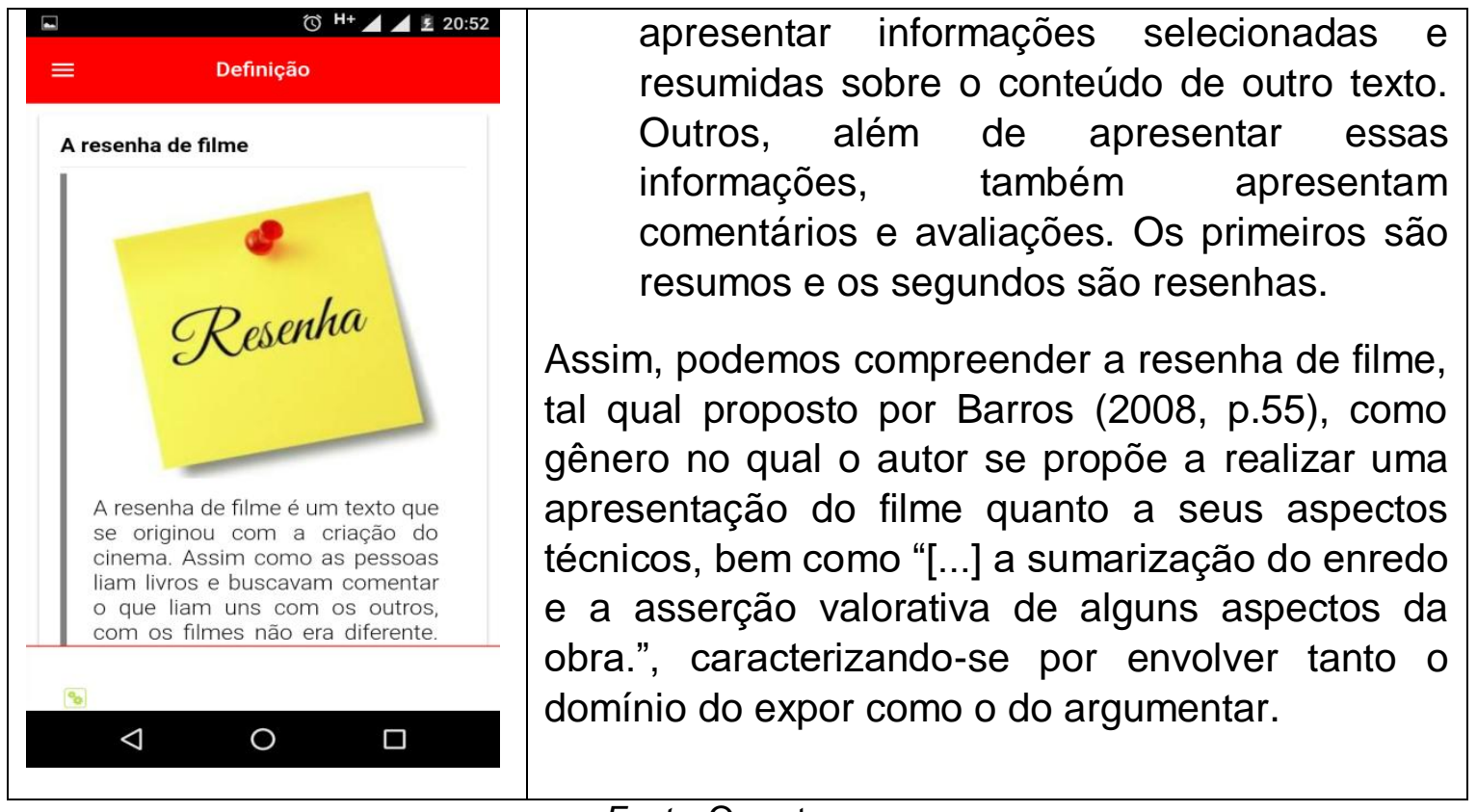

Fonte: Os autores

O menu Contexto de Produção apresenta informações acerca de elementos como campo/esfera de circulação, suporte, interlocutores, finalidade, entre outros, bem como faz a distinção entre a resenha descritiva e a crítica. Além disso, são disponibilizados alguns links para que o usuário possa acessar conteúdos complementares às explicações, assim como exemplos do gênero em seu contexto real de circulação. Entre esses links, encontram-se duas vídeo resenhas, que consistem na adaptação do gênero resenha para esfera digital.

Quadro 5 - Contexto de Produção

\begin{tabular}{|l|l|}
\hline 1. A resenha pode fazer parte do campo publicitário e \\
também do jornalístico. Os textos desses campos, \\
geralmente, buscam trazer informações, \\
entretenimento e atuar na divulgação de produtos e \\
serviços, estando ligados a valores culturais, \\
artísticos e de consumo. \\
2. O suporte no qual as resenhas de filmes são \\
publicadas podem ser: jornais, revistas ou sites. \\
3. Os interlocutores envolvidos são, de um lado, um \\
especialista ou alguém que possua vasto
\end{tabular}




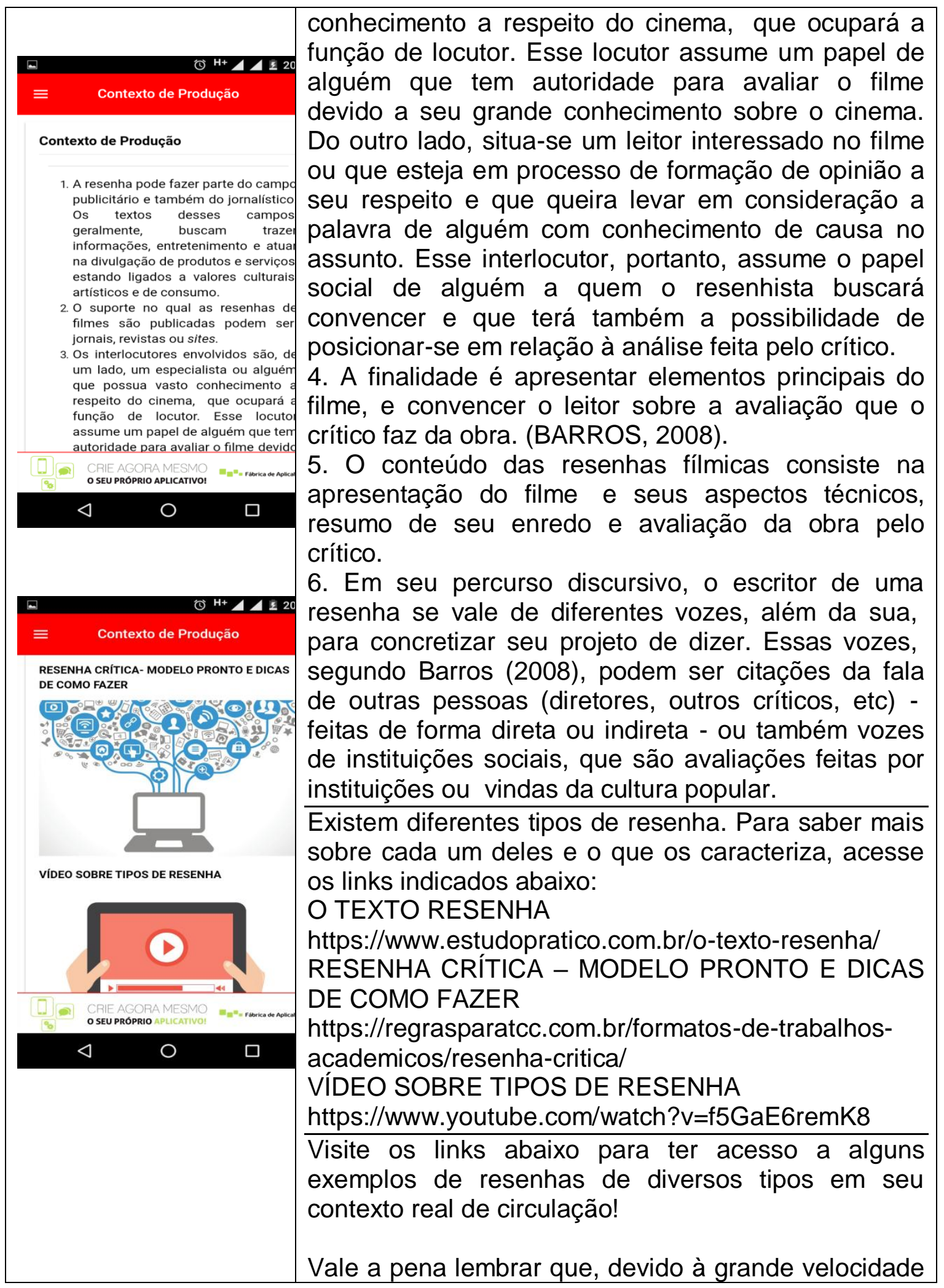

Pensares em Revista, São Gonçalo-RJ, n. 13, p. 137-164, 2018 


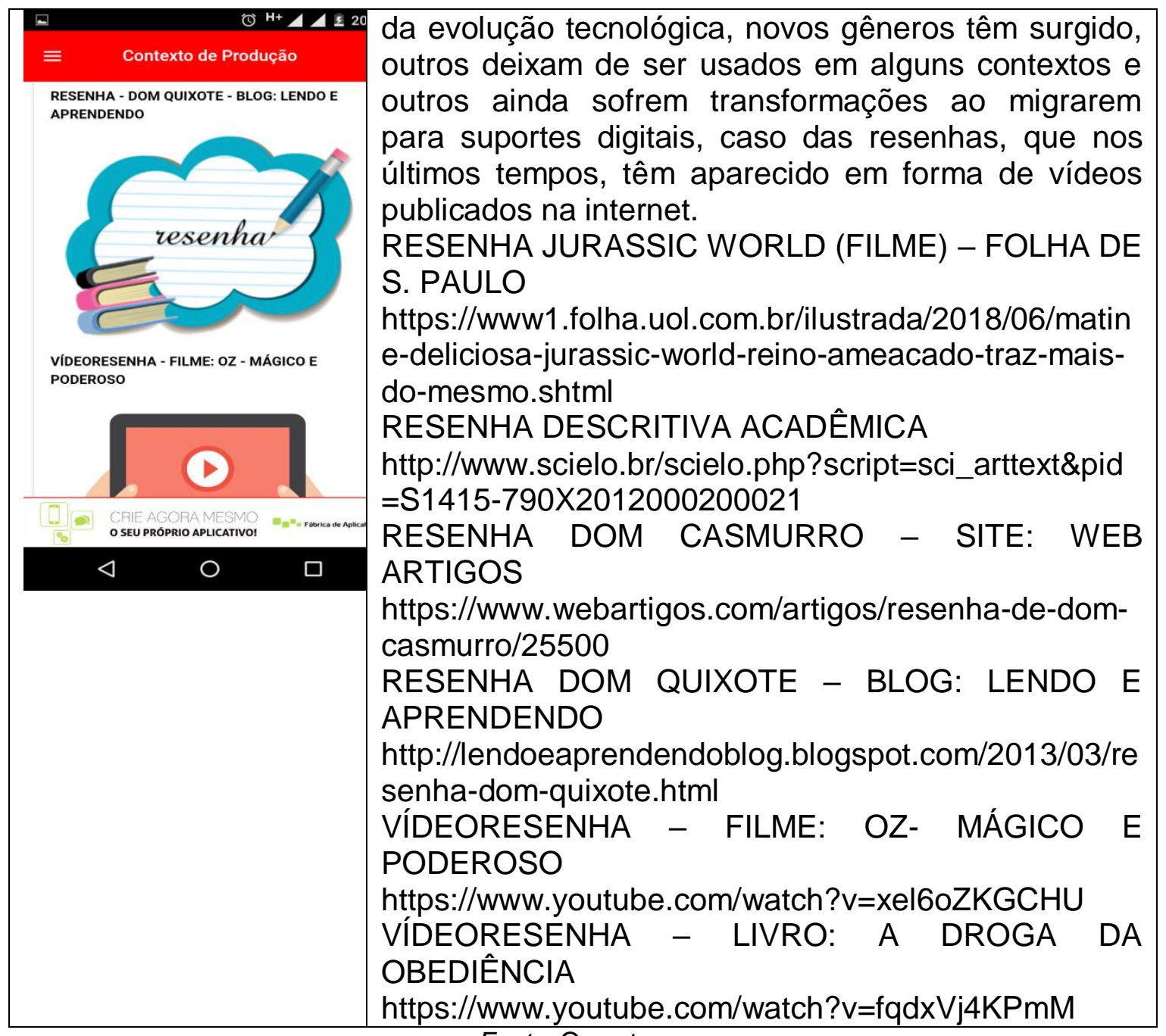
Fonte: Os autores

O próximo menu refere-se ao Conteúdo temático do gênero resenha de filme. 


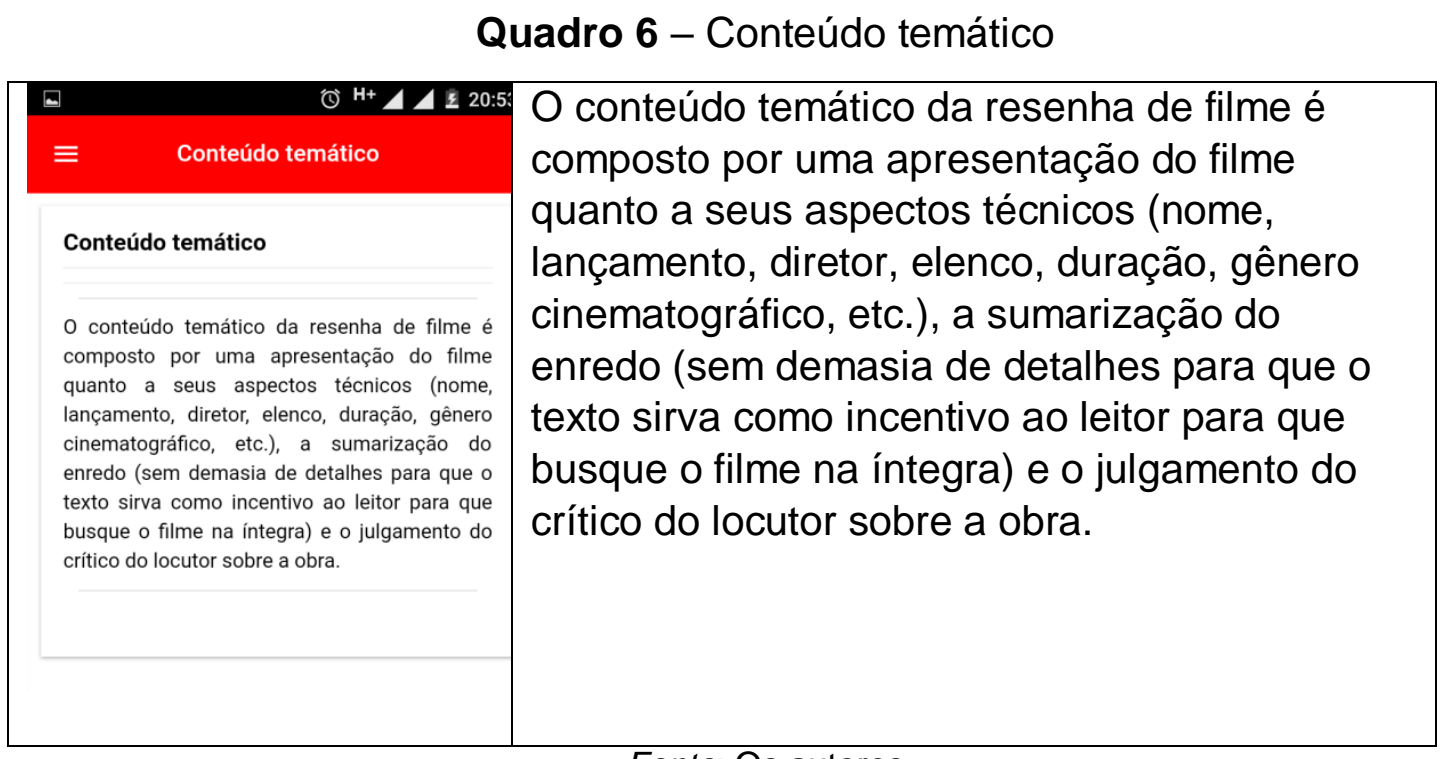

Fonte: Os autores

Em seguida, há o item referente à Estrutura composicional, no qual apresentamos, tendo por base os estudos de Barros (2008), um protótipo de estrutura a ser seguida pelas resenhas de filme.

Quadro 7 - Estrutura composicional

\begin{tabular}{|c|c|}
\hline$=\quad \sigma^{\mathrm{H+}} \boldsymbol{\Lambda} \backslash \geq 20: 53$ & $\begin{array}{l}\text { Apresentamos um protótipo de estrutura } \\
\text { composicional para a resenha baseando-nos em } \\
\text { Barros (2008): }\end{array}$ \\
\hline 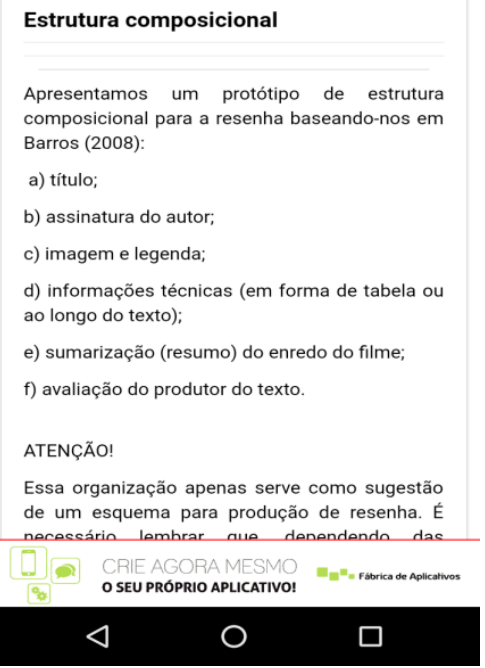 & $\begin{array}{l}\text { a) título; } \\
\text { b) assinatura do autor; } \\
\text { c) imagem e legenda; } \\
\text { d) informações técnicas (em forma de tabela ou } \\
\text { ao longo do texto); } \\
\text { e) sumarização (resumo) do enredo do filme; } \\
\text { f) avaliação do produtor do texto. } \\
\text { ATENÇÃO! } \\
\text { Essa organização apenas serve como sugestão } \\
\text { de um esquema para produção de resenha. É } \\
\text { necessário lembrar que, dependendo das } \\
\text { intenções de cada produtor, o texto poderá } \\
\text { apresentar variações com relação à estrutura }\end{array}$ \\
\hline
\end{tabular}




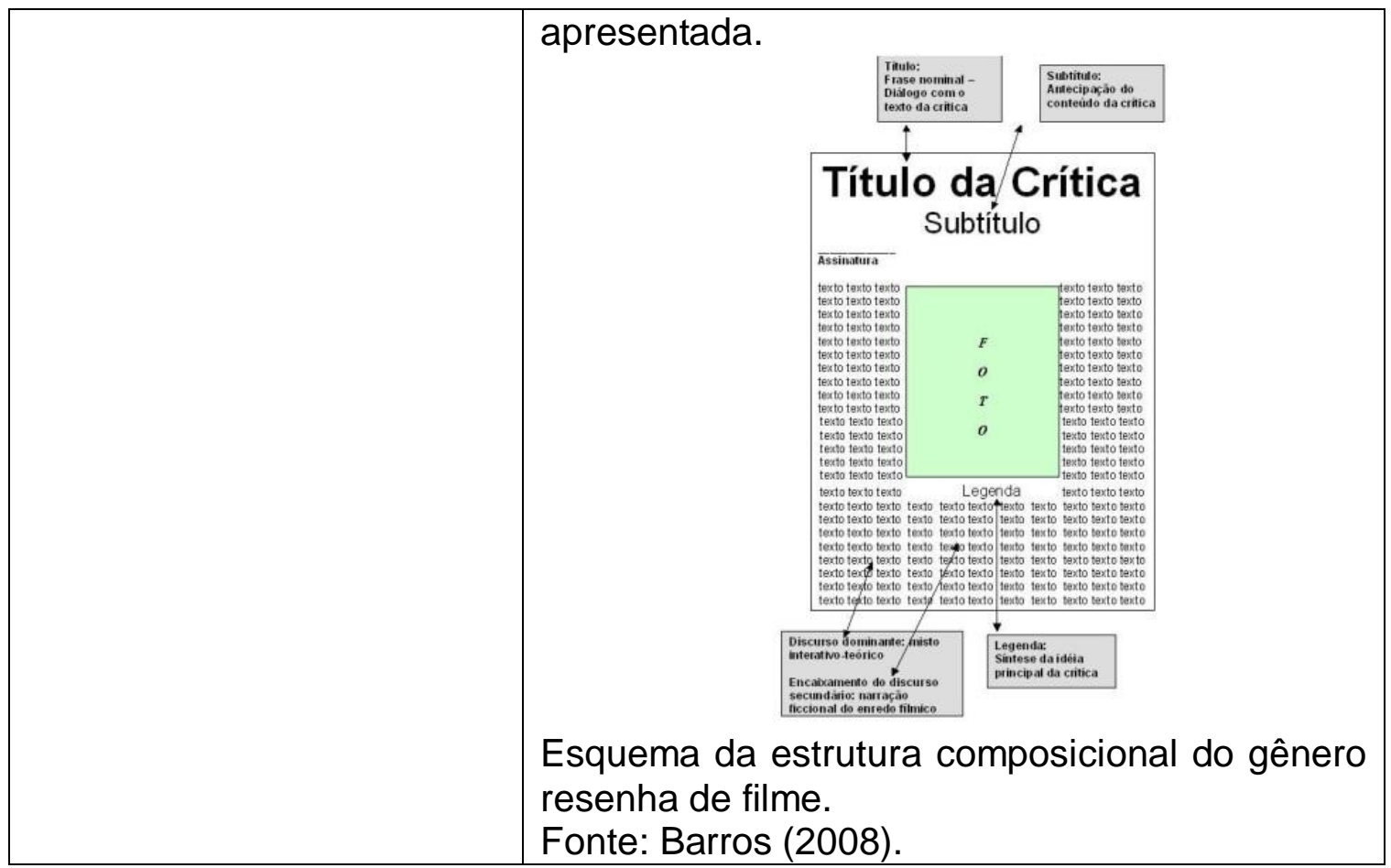

Fonte: Os autores

No menu Estilo, discutimos as escolhas linguísticas frequentemente realizadas por críticos de cinema ao produzir suas resenhas.

\section{Quadro 8 - EstilO}

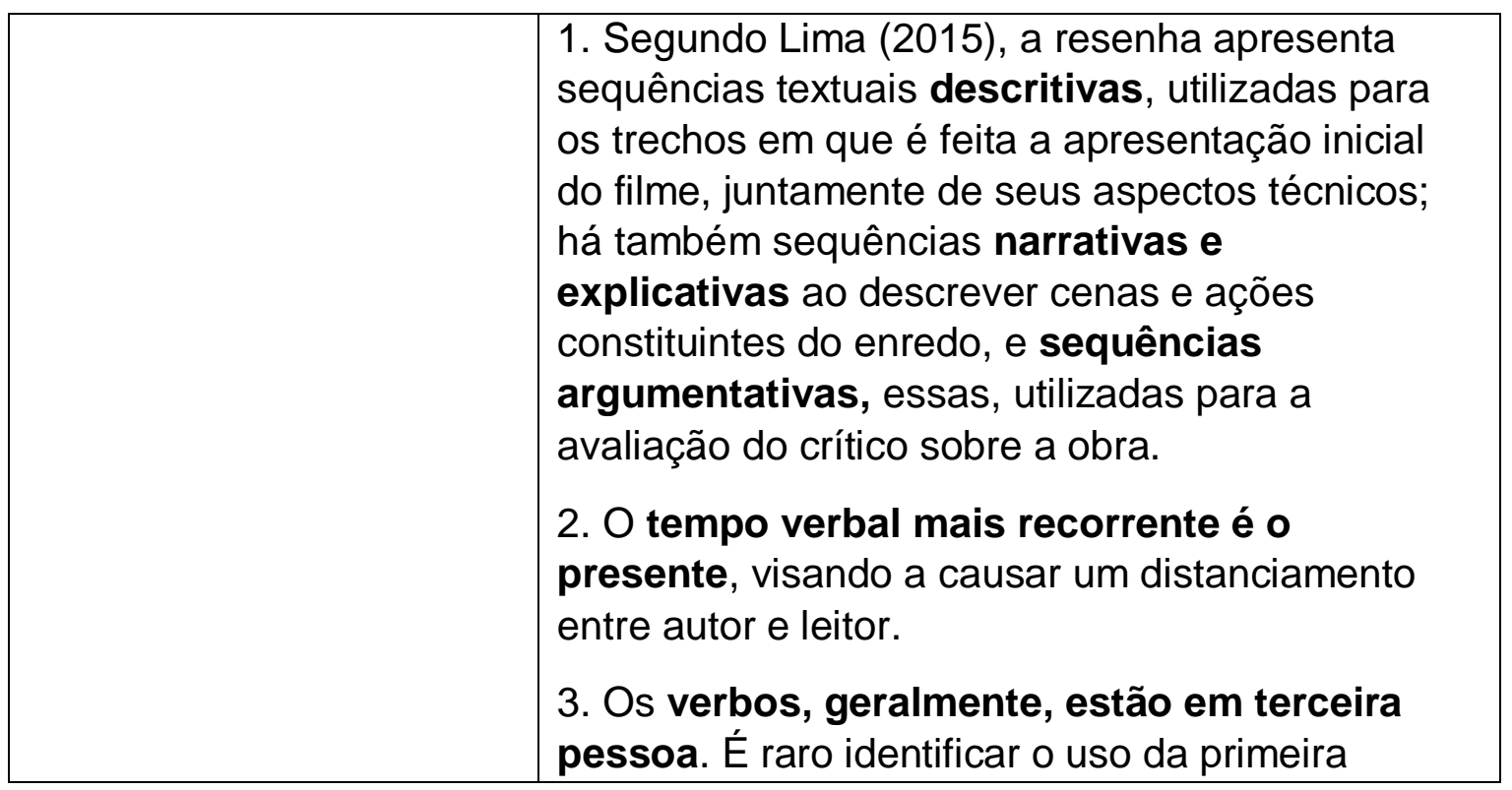




\begin{tabular}{|c|c|}
\hline 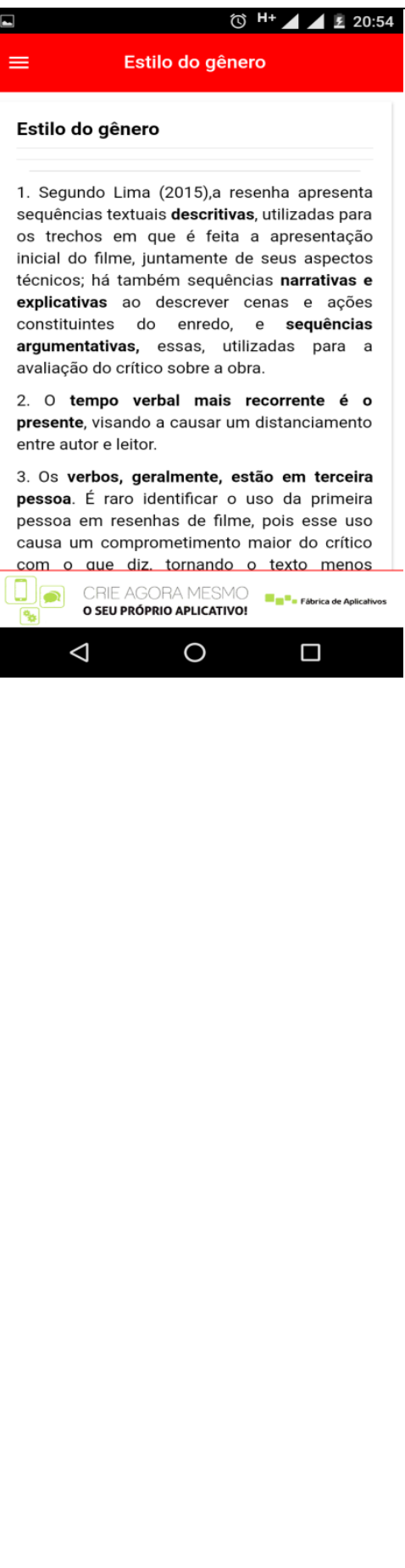 & $\begin{array}{l}\text { pessoa em resenhas de filme, pois isso causa um } \\
\text { comprometimento maior do crítico com o que diz, } \\
\text { tornando o texto menos objetivo. } \\
\text { 4. Os parênteses () são muito } \\
\text { utilizados, principalmente, para destacar o nome } \\
\text { dos atores que interpretam as personagens, mas } \\
\text { também podem ser usados para que o autor insira } \\
\text { comentários e informações extras durante o texto. } \\
\text { 5. As aspas também podem aparecer quando o } \\
\text { crítico deseja inserir vozes de outras } \\
\text { pessoas em seu texto, por meio de comentários } \\
\text { e citações. No caso das citações, teremos } \\
\text { também um verbo de dizer para introduzir a fala } \\
\text { do outro, como, por exemplo: O } \\
\text { diretor afirmou: "Fiquei contentíssimo com o } \\
\text { resultado desse filme!" } \\
\text { 6. Os conectivos (operadores lógico- } \\
\text { argumentativos) tem uma função de grande } \\
\text { importância na resenha, pois são eles que } \\
\text { conduzirão o raciocínio do crítico. } \\
\text { 7. Devido à necessidade de que o autor avalie a } \\
\text { obra, é comum haver várias expressões que } \\
\text { demonstram o ponto de vista do crítico sobre } \\
\text { ela (chamadas expressões modalizadoras), tais } \\
\text { como: adjetivos, advérbios, locuções adjetivas e } \\
\text { adverbiais e até mesmo alguns substantivos. } \\
\text { 8. Para garantir a continuidade do texto e evitar } \\
\text { repetir demasiadamente certas palavras, como o } \\
\text { nome do diretor, de algum ator ou mesmo do } \\
\text { filme, é muito comum o uso de substituições e } \\
\text { pronomes para retomar essas ideias } \\
\text { (referências anafóricas), para que o texto possa } \\
\text { progredir com fluidez. }\end{array}$ \\
\hline
\end{tabular}

Fonte: os autores 
Após essas discussões, inserimos um menu denominado Recapitulando, no qual retomamos as principais informações dos itens anteriores através de um quadro sinótico.

\section{Quadro 9 - Recapitulando}

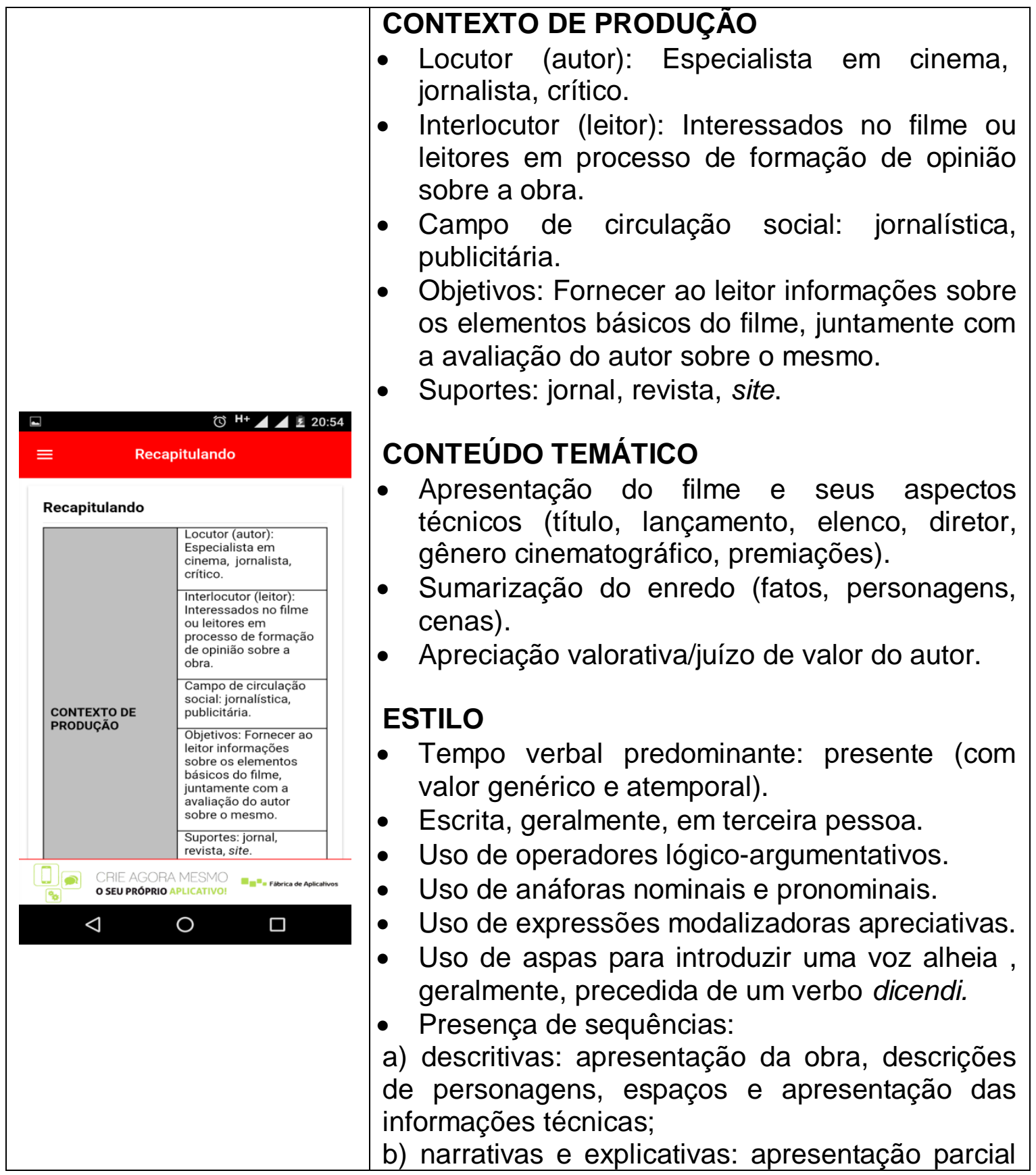




\begin{tabular}{|l|l|}
\hline do enredo e tema geral abordado pelo filme; \\
c) argumentativas: avaliação do produtor do texto \\
sobre o filme. \\
ESTRUTURA COMPOSICIONAL \\
- Protótipo do gênero (flexível) \\
a) título; \\
b) assinatura do autor; \\
c) imagens/fotos; \\
d) informações técnicas (em forma de tabela ou \\
distribuídas ao longo do texto); \\
e) sumarização aspectos principais do enredo do \\
filme; \\
f) avaliação do produtor do texto sobre a obra.
\end{tabular}

O menu de recapitulação é seguido pelo item Passos para a produção, cujo conteúdo é composto por dicas e passos que podem ser trabalhados com os alunos no intuito de que sejam capazes de realizar uma boa produção escrita do gênero resenha. O menu em questão também contém um link de um vídeo no qual uma youtuber que produz resenhas de filmes e livros compartilha com o público o processo de produção de seus textos.

Quadro 10 - Passos para produção

\begin{tabular}{|l|l|}
\hline Passo 1: Assista ao filme com muita atenção e, \\
enquanto estiver assistindo, se atenha a detalhes \\
como: \\
a) Enredo. \\
b) Figurino. \\
c) Trilha sonora. \\
d) Duração. \\
e) Adequação ao público-alvo. \\
f) Atuação do elenco. \\
g) Desempenho do diretor. \\
Passo 2: Selecione quais dos aspectos acima te \\
chamaram mais atenção no filme. Serão eles que \\
você comentará em sua resenha, pois não há \\
espaço suficiente para que todos sejam \\
analisados.
\end{tabular}




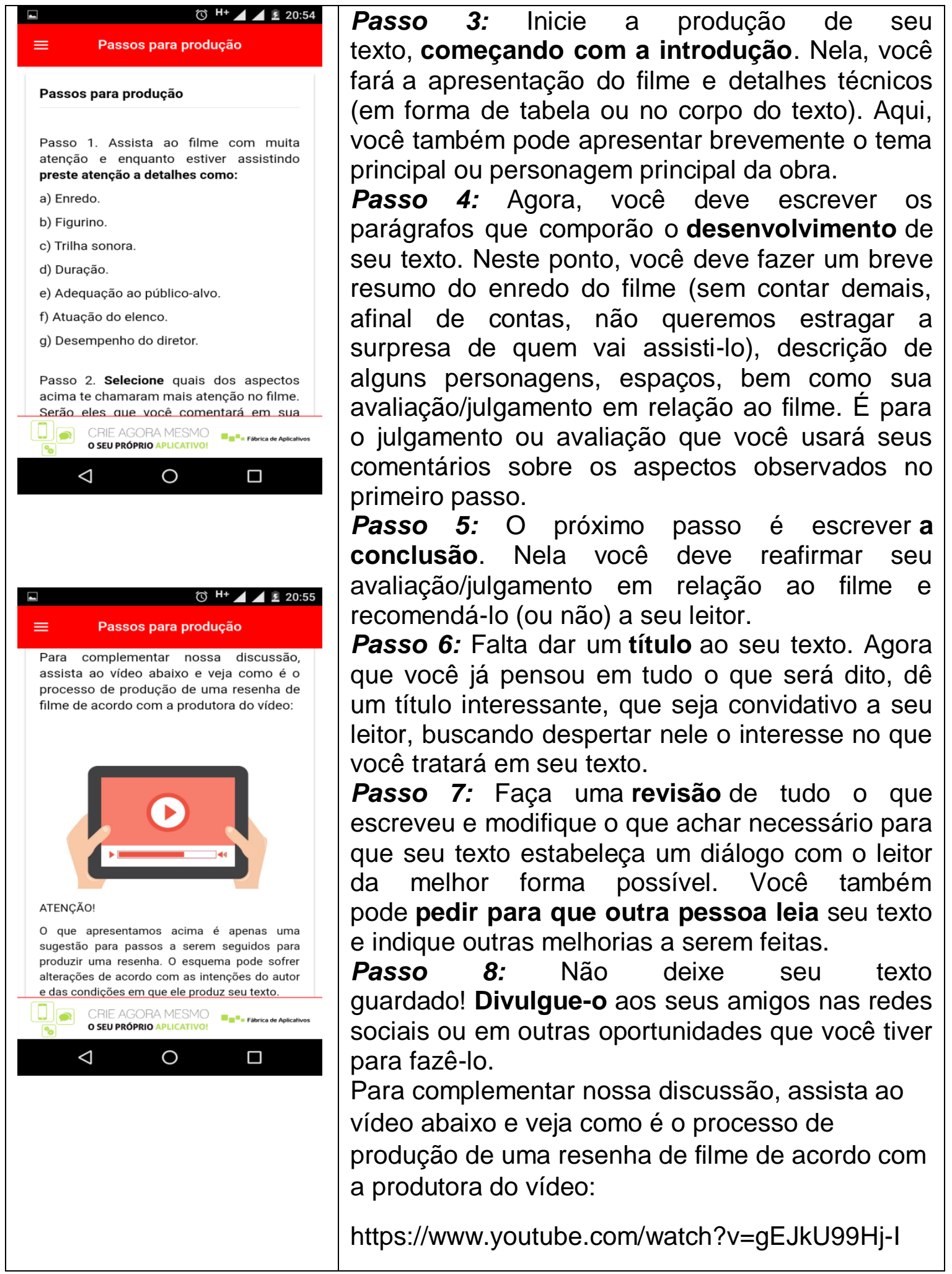

Pensares em Revista, São Gonçalo-RJ, n. 13, p. 137-164, 2018 


\begin{tabular}{|l|l|}
\hline ATENÇÃO! \\
O que apresentamos acima é apenas uma \\
sugestão de passos a serem seguidos para \\
produzir uma resenha. O esquema pode sofrer \\
alterações de acordo com as intenções de autor e \\
das condições em que ele produz seu texto.
\end{tabular}

Fonte: Os autores

O penúltimo item da ferramenta - Exemplos de resenha - apresenta quatro links com exemplos de textos pertencentes ao gênero resenha de filme, publicados em jornais e/ou revistas, seguidos de um quiz contendo questões que contemplam aspectos relevantes do conteúdo apresentado no aplicativo.

Quadro 11 - Exemplos de resenha: Modelos de resenha de filme e Quiz

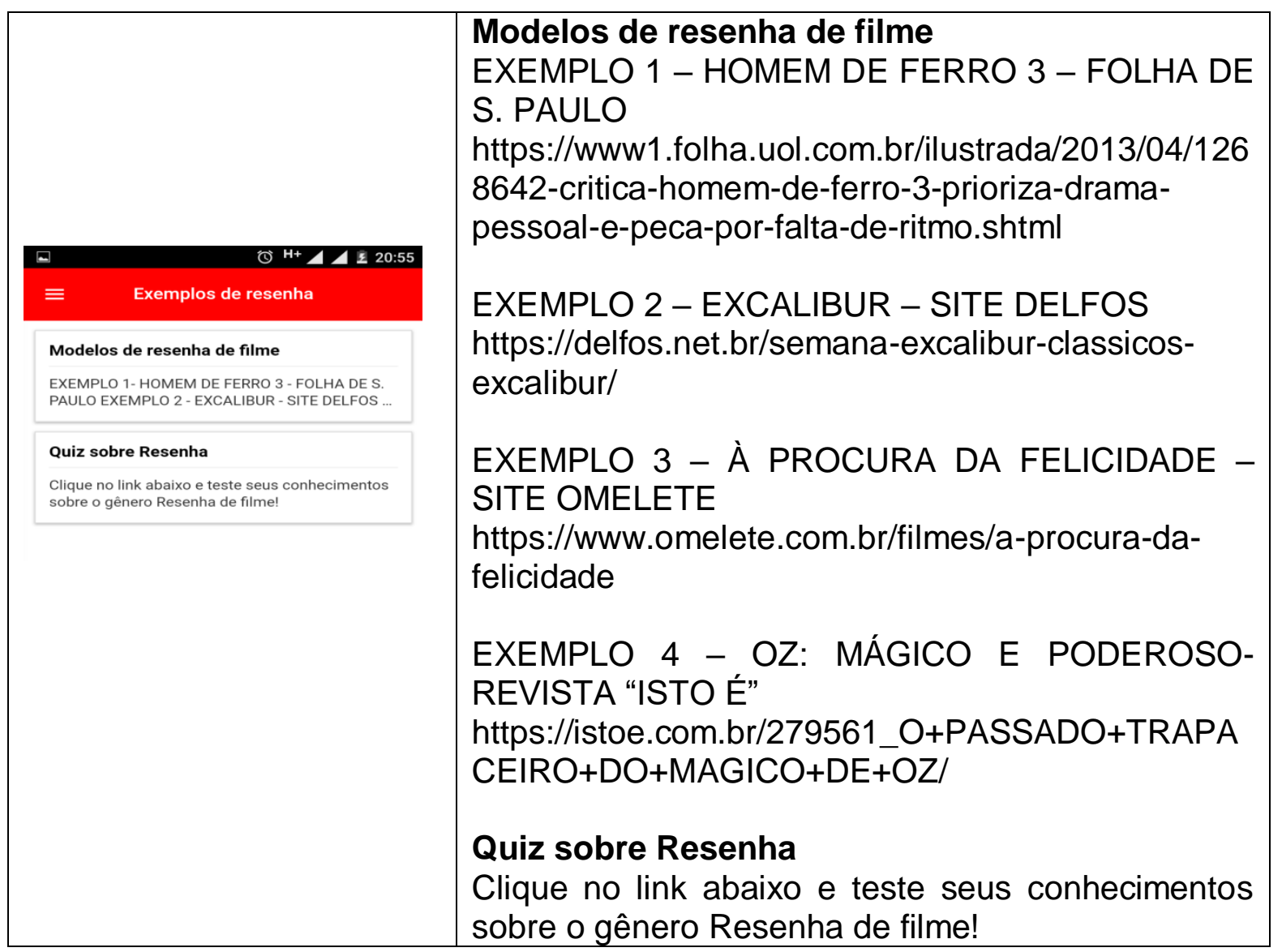




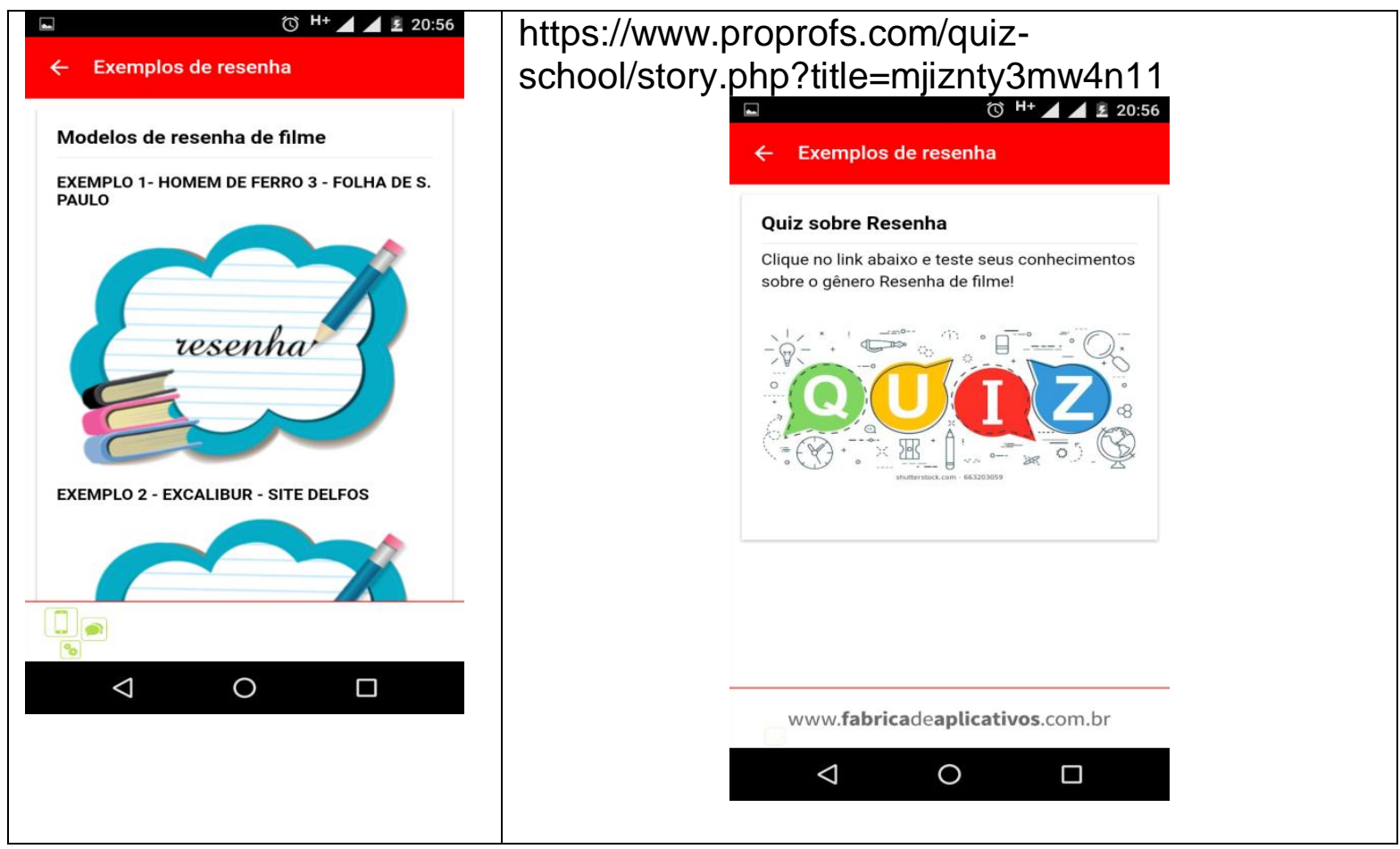

Fonte: Os autores

O aplicativo tem como último menu o item Referências, no qual são apresentados os estudos que deram embasamento para organizar o conteúdo do app, bem como se discorre sobre o contexto no qual a ferramenta foi produzida, contendo também um resumo do currículo de seus desenvolvedores.

\section{Considerações finais}

A construção de um app, como parte das atividades da disciplina "Gêneros discursivos/textuais e práticas sociais", no âmbito do ProfLetras denota, enquanto produto final, a internalização do conteúdo gênero resenha de filme por parte do professor em formação. Todavia, para que isso ocorresse, diversas operações anteriores foram realizadas, tanto pela professora 
formadora, como pelo professor, por meio da TA, como suporte metodológico para condução das ações.

O produto final - o app e o conteúdo por ele trazido não podem ser vistos isoladamente, como um único evento de apropriação. Na realidade, é preciso trazer à tona todo o movimento conceitual que a professora formadora gerou por meio de várias operações, primeiro de ordem coletiva (para todos os alunos) e depois de ordem individual.

A apropriação do gênero resenha de filme, como um pré-construído socialmente, necessitou de um processo consciente de mediação, de ferramentas adequadas a essa finalidade a fim de que pudesse instaurar no aluno uma real atividade. Além disso, de nada adiantaria operações bem planejadas sem o desejo do próprio professor, que sempre se dispôs a realizar todas as ações e operações sugeridas.

Fica exposto, assim, a possibilidade de que as aulas, não apenas no âmbito do Profletras, possam, seja com o apoio da TA (ou outras teorias), instaurar um movimento da reflexão crítica, propiciada pelo trabalho consciente de professores formadores com as ferramentas de ensino; pelo movimento do trabalho colaborativo dos alunos, no qual relações mais democráticas são vivenciadas; pelo movimento da investigação e do estudo devidamente mediados por operações; pelo movimento, enfim, tenso, contínuo, ininterrupto da própria vida e, por isso mesmo, sujeito às miopias de cada um de nós.

\section{Referências bibliográficas}

BARROS, E. M. D. A apropriação do gênero crítica de cinema no processo de letramento. 2008. 222f. Dissertação (Mestrado em Estudos da Linguagem). Centro de Letras e Ciências Humanas, Universidade Estadual de Londrina, Londrina. 2008.

DOLZ, J.; NOVERRAZ, M.; SCHNEUWLY, B. Sequências didáticas para o oral e a escrita: apresentação de um procedimento. In: SCHNEUWLY, B; DOLZ, J. 
Gêneros orais e escritos na escola. Trad. e org. ROJO, R.; CORDEIRO, G. S. São Paulo: Mercado das Letras, 2004, p. 95-128.

GUIMARÃES, A. M. de M; KERSCH, D.F. Explorando os projetos didático de gênero como um caminho metodológico. IN: Projetos didáticos de gênero no domínio do argumentar. Campinas: Mercado de Letras, 2014.

HALTÉ, J. F. O espaço didático e a transposição. Fórum Linguístico. Florianópolis: 5 (2), p.117-139, 2008.

HILA, C. V. D. Ferramentas curso de formação e sequência didática: contribuições para o processo de internalização do estágio de docência em língua portuguesa. 2011. 356f. Doutorado (Estudos da Linguagem) Universidade Estadual de Londrina, Londrina, 2011.

HILA, C. V. D. H.; NASCIMENTO, E.L. O carteiro chegou: uma proposta de sequência didática para as séries iniciais. Revista Prolíngua. João Pessoa, Universidade Federal da Paraíba, vol.2, p. 64-79, 2009.

LEONTIEV, A. Uma contribuição à teoria do desenvolvimento da psique infantil. In; VYGOTSKY, L.S.; LURIA, A. R.; LEONTIEV, A.N. (Orgs.) Linguagem, desenvolvimento e aprendizagem. Trad. De Maria da Penha Villalobos. 6.ed. São Paulo: Ícone, 1998.

Actividad, consciência e personalidad. La Habana: Editorial Pueblo y Educatión, 2001.

. O desenvolvimento do psiquismo. Trad. Rubens Eduardo Frias. 2.ed. São Paulo: Centauro, 2004.

LIMA, P. S. O gênero resenha na sala de aula: desenvolvendo as capacidades de linguagem. Revista Littera Online. Universidade Federal do Maranhão, v.6, n.10.p.1- 22, 2015. Disponível na internet: <http://www.periodicosele tronicos.ufma.br/index.php/littera/article/view/3563> Acesso em: 30 jan. 2018.

LOPES-ROSSI, M. A. G. Práticas de leitura de gêneros discursivos: a reportagem como proposta. In: PETRONI, M.R (Org) Gêneros do discurso, leitura e escrita: experiências de sala de aula. São Carlos: Pedro \& João Editores. Cuiabá, 2008, p.51-58

MACHADO, A. R.; LOUSADA, E.; ABREU-TARDELLI, L. S.. Resenha. São Paulo: Parábola, 2004. 
OLIVEIRA, M. do S.; TINOCO. G.A.; SANTOS. I.B. de A. Projetos de letramento e formação de professores de língua materna. $2^{\mathrm{a}}$. ed., Natal-RN: UFRN,2014.

ROJO, R.; MOURA, E. (orgs). Multiletramentos na escola. São Paulo: Parábola Editorial, 2012

SFORNI, M. S. de. Aprendizagem conceitual e organização do ensino: contribuições da teoria da atividade. 1. ed. Araraquara: JM Editora, 2004.

SWIDERSKI, R. M. da S.; COSTA-HUBES T. da C. Abordagem sociointeracionista \& sequência didática: relato de uma experiência. Revista Língua \& Letras. Cascavel: Unioste. P.113-12, 2009

ZACARIAS, V. S.; HILA, C. V. D. App como recurso metodológico para o ensino do gênero resenha de filme. Anais. II SEIPELL - Seminário Interinstitucional de Pesquisa em Literatura e Leitura. Maringá: UEM, 2018 (no prelo).

\section{Sobre os autores \\ Cláudia Valéria Doná Hila \\ Cursou Licenciatura em Letras-Português/Inglês e Literaturas Correspondentes (UEM), especialização em Conto Brasileiro Contemporâneo (UEM), mestrado em Linguística Aplicada (UEM) e doutorado em Estudos da Linguagem (UEL). Atualmente é professora adjunta de Língua Portuguesa no Departamento de Língua Portuguesa da UEM e atua no ProfLetras como coordenadora adjunta e professora. Desenvolve pesquisas sobre elaboração de materiais didáticos e gêneros discursivos. \\ Vinicius da Silva Zacarias \\ Graduado em Letras (Português/Inglês) pela Faculdade Estadual de Ciências e Letras de Paranavaí (FAFIPA), possui especialização em Ensino de Língua Inglesa e uso de novas tecnologias pela Universidade Gama Filho (UGF) e, atualmente, é mestrando do Programa de Pós-Graduação ProfLetras/UEM. Atua como professor da educação básica na rede estadual paulista de ensino.}

